\title{
MENINGKATKAN SKILL BERWIRAUSAHA MELALUI MANAJEMEN KEUANGAN ONLINE, INOVASI PRODUK, PENJUALAN ONLINE, DAN HANDYCRAFT
}

\author{
Siti Sumartiah ${ }^{1}$, Alfiatul Maulida ${ }^{2}$, Agus Dwi Cahya ${ }^{3}$, Salsa Bella Larasati ${ }^{4}$ \\ 1,2,3,4Prodi Manajemen, Universitas Sarjanawiyata Tamansiswa, \\ ${ }^{1}$ j.sitisumartiah@gmail.com, ${ }^{2}$ alfiatulmaulida@ustjogja.ac.id, ${ }^{3}$ agusdc@ustjogja.ac.id, \\ ${ }^{4}$ salsabellabantul18@gmail.com
}

\begin{abstract}
ABSTRAK
Abstrak: Tujuan dari kegiatan ini terciptanya produk dan bertambahnya pengetahuan tentang barang Handycraft misalkan tas dari kain percah, Skill dalam mengatur keuangan dibuktikan dengan serfikat pelatihan, Skill dalam menjual produk secara online dan dibuktikan dengan kepemilikan akun bisnis di social media sehinggan bisa mampu memberkan inovasi produk dan memperoleh konsumen yang lebih luas baik dari dalam negeri maupun luar negeri. Kegiatan yang dilaksanakan berupa pelatihan Manajemen Aset Online, Inovasi Produk, Penjualan Online, Dan Handycraft serta pratik. Hasil dari kuisioner online atas pelaksanaan kegiatan abdimas menunjukkan bahwa $100 \%$ peserta termotivasi untuk berwirausaha, $58 \%$ peserta memahami tentang inovasi produk, $100 \%$ peserta mengerti bagaimana membuat handycraft, dan $100 \%$ peserta mengerti dan memahami tentang promosi digital. Akantetapi, masih banyak yang kurang mengerti akan pengaplikasian manajemen keuangan online.

Kata Kunci: Manajemen Keuangan Online, Inovasi Produk, Penjualan Online, Dan Handycraft.

Abstract: The purpose of this activity is the creation of products and increasing knowledge about handicraft items such as bags made of woven cloth, skills in managing finances proven by training certificates, skills in selling products online and proven by ownership of business accounts in social media so that they can be able to provide product innovation and obtain product innovation wider consumers both domestically and abroad. The activities carried out in the form of training in Online Asset Management, Product Innovation, Online Sales, and Handicraft and practices. The results of the online questionnaire on the implementation of community service activities showed that $100 \%$ of participants were motivated to become entrepreneurs, $58 \%$ of participants understood about product innovation, 100\% of participants understood how to make handicrafts, and $100 \%$ of participants understood and understood about digital promotion. However, there are still many who do not understand the application of online financial management.
\end{abstract}

Keywords: Online Financial Management, Product Innovation, Online Sales, and Handicraft.

\section{A. LATAR BELAKANG}

Kewirausahaan memanglah bukan suatu hal yang tabu untuk didengar dan dipraktekkan. Banyak pemuda-pemudi yang sudah memulai dari dini bahkan dari masih kuliah, ibu-ibu rumah tanggapun tidak mau kalah bersaing dengan pemuda dan pemudi tersbut (Juanita, 2017). Bintaran kulon MG II, Wirogunan, Mergangsan, Yogyakarta, merupakan salah satu wilayah yang memiliki Ibu-ibu rumah tangga (IRT) yang berwirausaha rumahan, ada juga yang tidak berwirausaha tapi mempunyai keinginan 
untuk berwirausaha. Akan tetapi, IRT masih mempunyai masalah yang tidak dapat dielakkan sampai saat ini, yaitu minimnya skill kewirausahaan untuk meningkatkan perolehan laba yang selalu menurun dan bahkan merugi (Vernia, 2017), (Febrilia, Nasution, \& Handarini, 2017).

Tidak hanya itu, kurangnya skill kewirausahaan membuat IRT harus kebingungan saat penghasilan kepala rumah tangga tidak mencukupi kebutuhan bulanan rumah tangga (Sunarti, Hifzhan Frima Thousani, 2015). Kewirausahaan memanglah bukan suatu hal yang tabu untuk didengar dan di praktekkan. Pemberian pelatihan kewirausahaan meningkatkan keahlian sumber daya manusia mitra serta mampu untuk mengelola manajemen usaha, dan manajemen keuangan dengan baik (Sudarmadji, Dillak, \& Kadja, 2018). Banyak pemuda-pemudi yang sudah memulai dari dini bahkan dari masih kuliah, ibu-ibu rumah tanggapun tidak mau kalah bersaing dengan pemuda dan pemudi tersbut. Bintaran kulon MG II, Wirogunan, Mergangsan, Yogyakarta, merupakan salah satu wilayah yang memiliki Ibu-ibu rumah tangga (IRT) yang berwirausaha rumahan, ada juga yang tidak berwirausaha tapi mempunyai keinginan untuk berwirausaha. Akan tetapi, IRT masih mempunyai masalah yang tidak dapat dielakkan sampai saat ini, yaitu minimnya skill kewirausahaan untuk meningkatkan perolehan laba yang selalu menurun dan bahkan merugi. Tidak hanya itu, ketidak milikan dalam skill kewirausahaan membuat IRT harus kebingungan saat penghasilan kepala rumah tangga tidak mencukupi kebutuhan bulanan rumah tangga. Menajaga kualitas produk dengan meningkatkan inovasi produk serta menentukan harga barang secara tepat dapat memberikan keuntungan bagi wirausaha (Febrianti, 2017).

Banyaknya ibu-ibu rumah tangga yang hanya mengerjakan pekerjaan rumah tanpa ada kontribusi untuk meningkatkan perekonomian keluarga serta ada sebagian yang berwirausaha namun belum mampu untuk meningkatkan skill kirausahaan masing-masing sehingga pendapatan mereka cenderung stagnan/tetap bahkan menurun/rugi. Hal tersebut terjadi karena masih adanya kekurang mampuan ibu-ibu rumahtangga pelaku wirausaha dalam memanage keuangannya. Kemampuan menyusun laporan keuangan yang dimiliki pelaku usaha berpengaruh terhadap pelaku usaha dimana pelaku usaha akan kesulitan untuk memperoleh pinjaman modal dari pihak ketiga (Harahap, 2014). Selain itu, Keterbatasan wawasan dalam menginovasi produk dan memaksimalkan fungsi android mereka untuk berjualan via online.

Tujuan dari kegiatan ini terciptanya produk dan bertambahnya pengetahuan tentang barang Handycraft misalkan tas dari kain percah, Skill dalam mengatur keuangan dibuktikan dengan serfikat pelatihan, Skill dalam menjual produk secara online dan dibuktikan dengan kepemilikan akun bisnis di social media sehinggan bisa mampu memberkan inovasi produk dan memperoleh konsumen yang lebih luas baik dari dalam negeri 
Siti Sumartiah, Meningkatkan Skill Berwirausaha...

maupun luar negeri. Kegitan PKM akan memberikan manfaat pada IRT untuk Meningkatkan Skill Berwirausaha Melalui Manajemen Keuangan Online, Inovasi Produk, Penjualan Online, Dan Handycraft

\section{B. METODE PELAKSANAAN}

Kegiatan yang dilaksanakan berupa pelatihan Manajemen Aset Online, Inovasi Produk, Penjualan Online, Dan Handycraft serta pratik. Materi pelatihan disesuaikan dengan kebutuhan para IRT agar dapat menjawab berbagai permasalahan untuk meningkatkan skill kewirausahaan. Adapun kerangka pemecahan masalah sesuai Gambar 1 berikut.
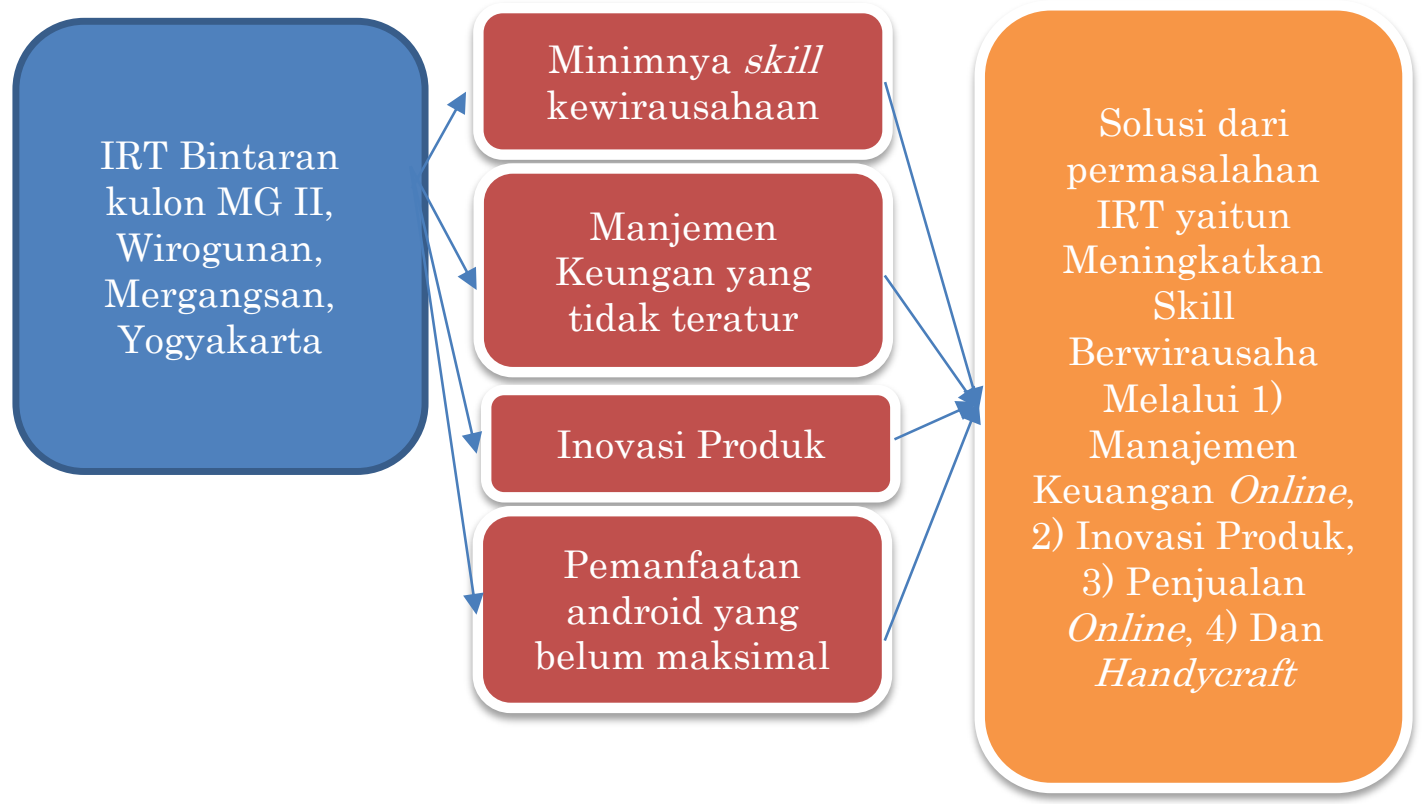

Gambar 1. Kerangka Pemecahan Msalah

IRT Bintaran kulon MG II, Wirogunan, Mergangsan, merupakan salah satu Kelurahan yang ada di Yogyakarta dimana ibu rumah tangga di kawasan ini mempunyai permasalah minimnya skill berwirausaha, manajemen keuangan yang tidak teratur, inovasi produk, dan pemanfaatan android yang belum maksimal sehingga membuat IRT kesulitan untuk memperoleh pemasukan tambahan. Adanya permasalahan tersebut, dapat di selesaikan menggunakan peningkatan skill berwirausaha, manajemen keuangan online, penjualan online, dan handycraft.

Pada tahap persiapan, tim pengabdian ini melaksanakan beberapa kegiatan, di antaranya koordinasi dengan para peserta melalui penyebaran undangan pelatihan Manajemen Aset Online, Inovasi Produk, Penjualan Online, Dan Handycraft yang menjadi sasaran pengabdian. Langkah berikutnya ialah persiapan pembuatan modul pelatihan Manajemen Aset Online, Inovasi Produk, Penjualan Online, Dan Handycraft dengan rincian materi sesuai Tabel 1 berikut:

Tabel 1. Topik Materi Pelatihan

\begin{tabular}{ll}
\hline \multicolumn{1}{c}{ Topik Pre-Test } \\
\hline 1 & Ide Berwirausaha \\
\hline 2 & Manajemen Aset Online \\
\hline 3 & Inovasi Produk \\
\hline
\end{tabular}




\begin{tabular}{ll}
\hline 4 Penjualan Online & \\
\hline 5 Praktek Handycraft & \\
\hline & \\
&
\end{tabular}

Adapun langkah-langkah penyampaian materi pada pelatihan ini sebagai berikut:

1. Ide Berwirausaha. Peserta diberikan materi tentang ide-ide berwirausaha dimana peserta mendapat materi tentang hal tersebut melalui metode ceramah yang di sampaikan oleh Bapak Agus Dwi Cahya, S.Pd., M.M.

2. Inovasi Produk. Sesi Inovasi Produk diawali dengan pemberian berbagai gambar macam produk produk olahan tradisional hingga menjadi produk yang mempunyai nilai tinggi kemudian dilanjutkan dengan pemberian materi tentang inovasi produk dimana metode yang digunakan ialah metode ceramah dengan memanfaatkan proyektor yang ada. Sesi ini disampaikan oleh Bapak Agus Dwi Cahya, S.Pd., M.M.

3. Manajemen Keuangan Onlline. Penyampaian materi manajemen keuangan online disampaikan oleh Ibu Alfiatul Maulida, S.E., M.M. dimana penyampaian materi ini mengguankan metode praktek dan caramah. Peserta dipandu untuk mendownload aplikasi yang di sarankan. Kemudian, peserta mempraktekan dan dipandu dalam memasukkan data-data yang perlu untuk dicatat dalam aplikasi tersebut sehingga bisa mempermudah peserta dalam mengelola keuangan dengan efektif dan efisien.

4. Penjualan Online. Metode yang digunakan pada penyampaian materi ini menggunakan metode ceramah dimana peserta diminta untuk langsung mempraktekkan promosi secara online salah satunya menggunakan sosial media seperti WhatsApp. Sesi ini disampaikan oleh Bapak Agus Dwi Cahya, S.Pd., M.M.

5. Handycraft. Pelaksanaan pelatihan handycraft dilaksanakan dengan langsung mempraktekkan barang/produk yang akan dijadikan bahan praktek. Pada proses ini, peserta akan mempraktekkan 2 barang handycraft yaitu gantungan kunci dan gantungan baju hiasan. Pemberi pelatihan ini ialah Ibu Siti Sumartiah, S.H., M.H.

Selanjutnya, untuk mengukur tingkat keberhasilan kegiatan pengabdian ini, peserta diberikan kuesioner pre-test (sebelum) pelatihan dan kuesioner post-test (sesudah) pelatihan dalam bentuk kuesioner online yang berisi tes pengujian kemampuan literasi informasi. Tahap ini dimaksudkan untuk mengetahui kemampuan literasi informasi para peserta pelatihan. Berikut merupakan daftar pertanyaan yang diajukan pada kegiatan pelatihan. Berikut Daftar Pertanyaan yang dibuat dengan Google Form: 


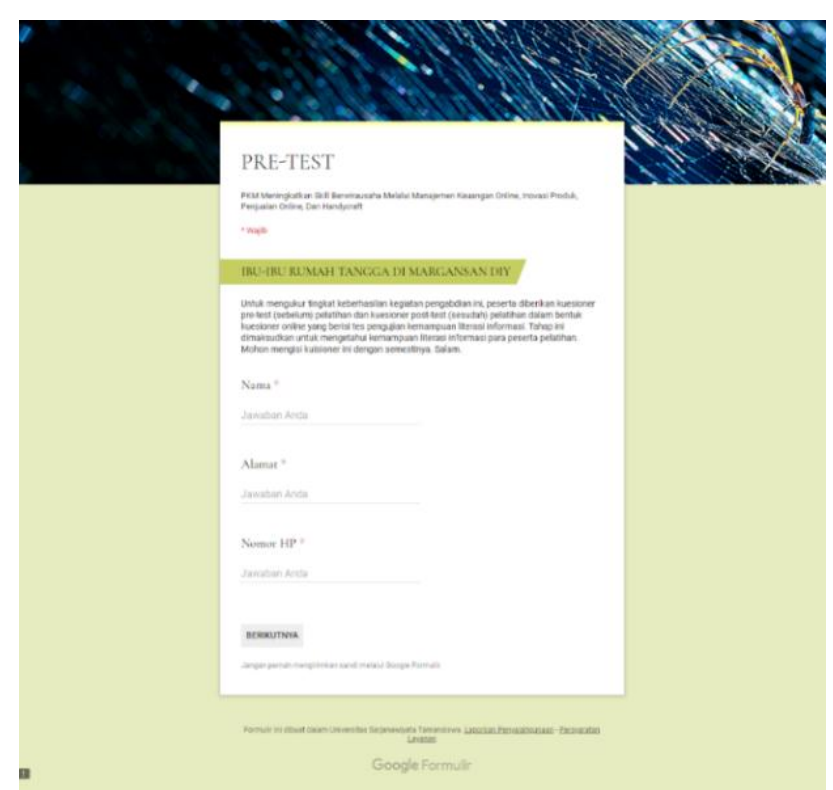

Gambar 2. Kuisioner Pre Test : $\underline{\text { http://bit.ly/2rTnJK6 }}$

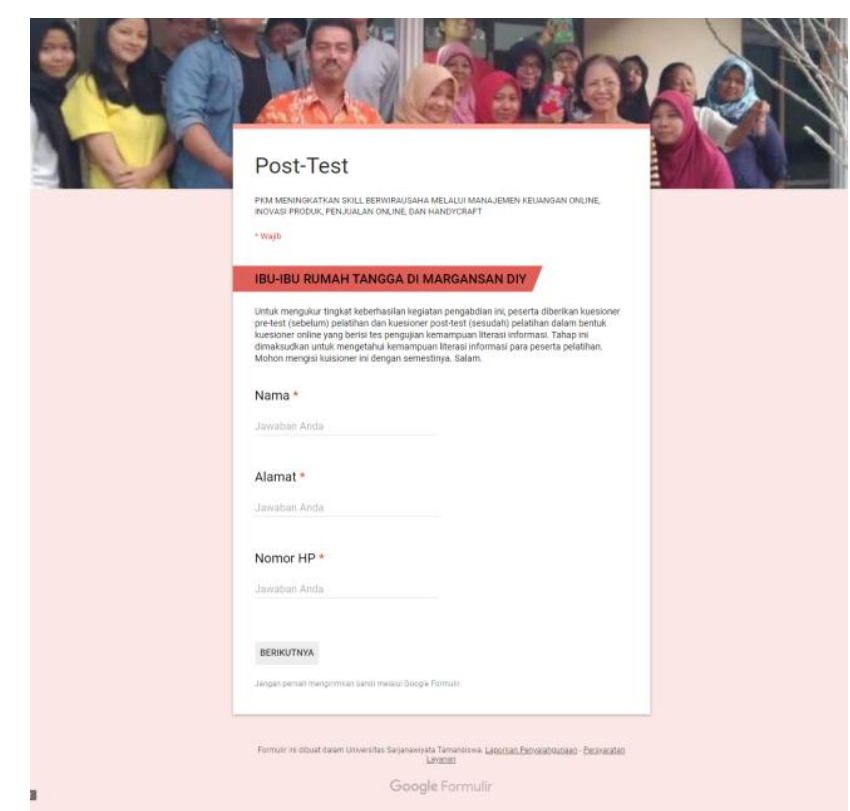

Gambar 3. Kuisioner Post Test: $\underline{\text { http://bit.ly/2rPtQze }}$

\section{HASIL DAN PEMBAHASAN}

Hari ke-1 pada kegitatan abdimas yang di danai oleh LP3M sebagai kegiatan tahunan. Dilaksankana pada hari Senin tanggal 8 Agustus 2019. Kegiatan ini diawali dengan perkenalan pemateri dengan Ibu-ibu peserta kegiatan ABDIMAS. Ternyata ketika kegiatan sudah akan dimulai, pemuda pemudi RT mergansan datang untuk meminta ijin mengikuti kegiatan ABDIMAS kami dan dengan senang hati kami mempersilakan mereka mengikuti kegiatan ini. 


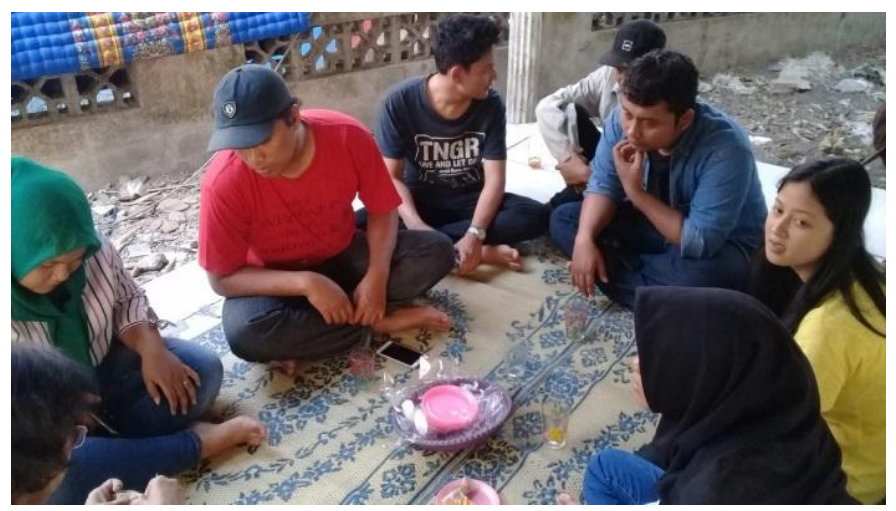

Gambar 4. Pemuda Pemudi Mergansan saat Mengikuti Pelatihan

Setelah memperkenalkan diri kepada peserta kegiatan mulailah PreTest diberikan melalui share link kuisioner menggunakan googleform kepada peserta menggunakan Whatsup. Setelah peserta mengisi Pre-Test, selanjutnya dilanjutkan dengan pemeberian materi Pengenalan Kewirausahan dan kiat-kiat berwirausaha sukses, inovasi produk, serta penjualan online dan manjemen keuangan online.

Hari ke-2 dilaksanakan pada Hari Jumat tanggal 9 Agustus 2019. Kegiatan dilaksanakan dirumah warga mergansan dengan materi praktek handycraft. Pada hari kedua hanya difokuskan untuk membuat handycraft diharapakan warga atau peserta kegiatan ABDIMAS mampu membuat handycraft.

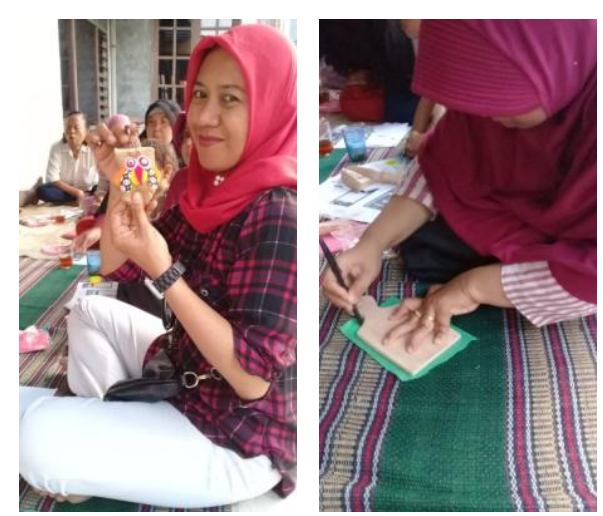

Gambar 5. Parga sedang memperlihatkan hasil praktek bahan ke-1 (kiri), Warga sedang mempraktekkan bahan ke-2 (kanan)

Sebelum kegitan ABDIMAS benar-benar selesai, maka Post-Test diberikan kepada peserta pelatihan pada hari ke-2 diberikan melalui share link kuisioner menggunakan googleform kepada peserta menggunakan Whatsup. Berikut hasil kuisioner post-test:

\section{Pemahaman Tentang Ide Berwirausaha}

Setelah pemeberian materi tentang ide berwirausaha dan motivasi untuk berwirausaha, $100 \%$ peserta pelatihan memberikan jawaban bahwa mereka mengigikan untuk berwirausaha. Peserta menginginkan untuk berwirausaha sebagai pedagang, pengrajin, penenun, dan sebagainya. 


\section{Pemahaman Tentang Inovasi Produk}

Setelah pemeberian materi tentang Inovasi Produk, peserta pelatihan memeberikan jawaban bahwa $41,2 \%$ masih belum mengerti atau tahu tentang inovasi produk, dan 58.8\% sangat mengerti tantang inovasi produk setelah diberikan materi tentang inovasi produk dari pemateri.

\section{Pemahaman Tentang Penjualan Online}

Setelah diberikannya pelatihan tentang manajemen keuangan online, masih banyak yang kurang mengerti akan pengaplikasiannya. Berikut hasil dari kuisioner online:

\section{Pemahaman Tentang Penjualan Online}

Dari 17 Responden, 100\% peserta menjawab mengerti tentang penjualan online setelah diberikannya materi tentang digital marketing.

\section{Pemahaman Tentang Handycraft}

Setelah diberikannya pelatihan tentang pelatihan Handycraft, $100 \%$ peserta mengerti dan mulai membuat handycraft.

\section{SIMPULAN DAN SARAN}

Kegitatan ABDIMAS yang dilaksanakan di Mergansan Kota Yogyakarta berlangsung selama 2 hari, yaitu hari Kamis dan Jumat. Perserta kegiatan ABDIMAS diikuti oleh Ibu-ibu Rumah Tangga dan Pemuda Pemudi di mergansan. untuk mengetahui ketercapaian kegitan ini digunakan Pre-Test dan Post-Test secara online menggunakan googleform. Adanya pelaksanaan kegiatan abdimas menunjukkan bahwa $100 \%$ peserta termotivasi untuk berwirausaha, 58\% peserta memahami tentang inovasi produk, 100\% peserta mengerti bagaimana membuat handycraft, dan $100 \%$ peserta mengerti dan memahami tentang promosi digital. Akantetapi, masih banyak yang kurang mengerti akan pengaplikasian manajemen keuangan online.

Saran dari peserta, warga mergansan mengarap pelaksanaan pengabdian kegitan masayarakat yang di adakan dilaksanakan secara berkelanjutan sehingga mampu memberikan dan mendapingi peserta untuk melaksanan pelatihan dan praktek pembuatan handycraft, manajemen keuangan online, inovasi produk, penjualan online secara maksimal.

\section{UCAPAN TERIMA KASIH}

Tim penulis mengucapkan terima kasih kepada LP3M Universitas Sarjanawiayata Tamansiswa Yogyakarta yang telah mendanai kegiatan pengabdian ini sehingga terlaksana dengan baik. Ucapan Terimakasih yang sangat dalam dari sanubari teruntuk mitra ABDIMAS ini, yaitu warga Bintaran Kulon, Mergansan, Kota Yogyakarta. 


\section{DAFTAR RUJUKAN}

Febrianti, A. M. (2017). The influence of creativity, price determination to publicity and their impact to the purchasing power of customers. Journal of Environmental Management and Tourism. https://doi.org/10.14505/jemt.v8.6(22).05

Febrilia, I., Nasution, H., \& Handarini, D. (2017). Pelatihan Penggunaan Jejaring Sosial Instagram Dalam Memasarkan Barang Pada Ibu-Ibu Pkk Di Kelurahan Rawamangun Jakarta Timur. Sarwahita, 14(02), 108-113. https://doi.org/10.21009/sarwahita.142.04

Harahap, Y. R. (2014). Kemampuan Menyusun Laporan Keuangan Yang Dimiliki Pelaku Ukm Dan Pengaruhnya Terhadap Kinerja Ukm. Jurnal Riset Akuntansi Dan Bisnis.

Juanita, S. (2017). Analisa Strategi Bisnis Penjualan Online. Konferensi Nasional ICT-M Politeknik Telkom, 254-260.

Sudarmadji, P. W., Dillak, R. Y., \& Kadja, J. P. Z. R. (2018). PPPE Kerajinan Tangan (Handicraft) Berbahan Limbah Perca Kain Tenun Ikat. JPP IPTEK (Jurnal Pengabdian Dan Penerapan IPTEK), 2(2), 17-26. https://doi.org/10.31284/j.jpp-iptek.2018.v2i2.289

Sunarti, Hifzhan Frima Thousani, A. F. (2015). Upaya Pengembangan E-Business Dalam Pemasaran Produk Secara Internasional (Studi pada Akademi Bisnis Online Indonesia Surabaya). Jurnal Administrasi Bisnis, Vol. 23(1).

Vernia, D. M. (2017). Optimalisasi Media Sosial Sebagai Sarana Promosi Bisnis Online Bagi Ibu Rumah Tangga Untuk Meningkatkan Perekonomian Keluarga. UTILITY: Jurnal Ilmiah Pendidikan Dan Ekonomi, 1(2), 105-118. 